\title{
PENCEGAHAN PENYAKIT DEGENERATIF MELALUI GERAKAN SEHAT BERBASIS MASJID (REHATSIMAS)
}

\section{PREVENTION OF DEGENERATIVE DISEASES THROUGH MOSQUITO-BASED HEALTH MOVEMENT (REHATSIMAS)}

\author{
Erna Rochmawati \\ Program Studi Magister Keperawatan, Program Pascasarjana \\ Universitas Muhammadiyah Yogyakarta \\ Jl Brawijaya Tamantirto Kasihan, Bantul, DI Yogyakarta \\ Email: erna.rochmawati@umy.ac.id
}

\begin{abstract}
ABSTRAK
Peningkatan fungsi masjid selain untuk sarana ibadah dapat dilakukan untuk peningkatan kesehatan umat. Kegiatan ini menggabungkan tindakan pencegahan (edukasi, olahraga dan deteksi dini) dengan meningkatkan fungsi masjid untuk kesehatan umat. Tujuan kegiatan adalah tercapainya upaya preventif terhadap resiko terjadinya penyakit degeneratif dan resiko komplikasi pada masyarakat, deteksi dini dan senam kaki. Metode yang digunakan adalah memberikan pendidikan kesehatan, pemeriksaan tekanan darah dan kadar gula darah, dan pelaksanaan senam kaki. Pendidikan kesehatan dilakukan dua kali, yaitu dalam kelas besar dan individu yang mengalami hasil skrining abnormal. Skrining dilakukan dengan menggunakan tensimeter dan glucotest, sedangkan senam dilakukan dalam kelompok kecil. Hasil kegiatan menunjukkan peserta mengetahui tanda dan gejala serta penatalaksanaan hipertensi.Terdapat produk berupa dua leaflet tentang hipertensi dan penatalaksanaanya. Hasil skrining 1 dan 2 lebih dari 50\% tekanan darahnya melebihi batas normal (>130/90 mmHg). Dari segi ketrampilan, didapatkan 5 peserta dapat melakukan redemonstrasi senam kaki dengan baik. Kegiatan ini perlu dilanjutkan dengan cara peer education dan pemilihan champion dari warga setempat untuk meningkatkan kepatuhan terhadap penatalaksanaan hipertensi dan diabetes mellitus.
\end{abstract}

Kata kunci: Diabetes Mellitus; Hipertensi; Pendidikan Kesehatan; Senam Kaki

\begin{abstract}
Improving the function of the mosque in addition to the means of worship can be done to improve the health of the people. The community service combines prevention measures (education, sports, and early detection) by enhancing the function of mosques for the health of the people. The purpose of this community service was three, namely the achievement of preventive efforts towards the risk of degenerative diseases and the risk of complications in the community in two mosques in the villages of Ngestiharjo, Kasihan, Bantul, Yogyakarta, earl health screening and foot exercises. The method included providing health education, checking blood pressure and blood sugar levels, and conducting foot exercises. Health education was carried out twice, in large classes and individuals who experience abnormal screening results. Health screening was performed using tensimeter and glucose. Gymnastics was carried out in a small group. The results of community service are participants understand the signs and symptoms and management of hypertension. There are two products in the form of two leaflets about hypertension and management. The results of screening 1 and 2 more than 50\% of blood pressure exceed the standard limit (> 130/90 $\mathrm{mmHg}$ ). In terms of skills, 5 participants were able to demonstrate foot gymnastics adequately. This activity needs to be continued using peer education and selection of champions from residents to improve adherence to the management of hypertension and diabetes mellitus.
\end{abstract}

Keywords: Diabetes Mellitus; Hypertension; Health Education; Foot Exercise 


\section{PENDAHULUAN}

Pada saat ini, penyakit degeranatif merupakan penyakit utama yang menyebabkan kematian di dunia. Hipertensi sebagai contoh adalah penyebab utama kematian dan komplikasi penyakit lain di dunia (Mills et al., 2016). Penyakit lain, misalnya diabetes mellitus juga dikatakan merupakan kegawatan kesehatan baik pada tingkat lokal dan global (Al-Lawati, 2017). Peningkatan angaka pada penyakit degeneratif ini terjadi hampir di setiap negara tidak terkecuali Indonesia.

Indonesia pada bidang kesehatan saat ini menghadapi dua hal utama, yaitu penyakit infeksi/menular dan meningkatnya jumlah penderita penyakit tidak menular. Pasien dengan penyakitdegeneratifdi Indonesia selalu mengalami peningkatan dari tahun ke tahun yaitu pada tahun 2007 sebanyak 9,4 $\%$ menjadi $13,3 \%$ pada tahun 2013 (Kementrian Kesehatan, 2018) Di Indonesia angka kejadian penyakit degeneratifyaitu stroke sebanyak 1.236.825 orang, penyakit hipertensi sebanyak 84.345 orang, Diabetes Mellitus sebanyak 10 juta orang, penyakit jantung sebanyak 883.447 orang dan penyakit kanker sebanyak 330.000 dengan kejadian tertinggi berada di Yogyakarta (Kementrian Kesehatan, 2018).

Meningkatkan prevelensi penyakit degeneratif di beberapa negara berkembang akibat peningkatan kemakmuran di negara bersangkutan akhir-akhir ini banyak disoroti. Peningkatan perkapita dan perkembangan gaya hidup terutama di kota-kota besar, menyebabkan peningkatan penyakit degeneratif. Hal ini berkaitan dengan jumlah populasi meningkat, pola hidup, prevalensi obesitas meningkat dan kegiatan fisik kurang (Smeltzer \& Bare, 2002). Berdasarkan laporan dari WHO mengenai studi populasi diabetes mellitus diberbagai negara, jumlah penderita diabetes mellitus pada tahun 2000 di Indonesia menempati urutan ke-4 terbesar dalam jumlah penderita diabetes mellitus dengan pravelensi 8,4 juta jiwa. Urutan diatasnya adalah India (31,7 juta jiwa), China (20,8 juta jiwa), dan Amerika Serikat (17,7 juta jiwa) (2007 (Al-Lawati, 2017).

Penyakit tidak menular sebagian besar merupakan penyakit degeneratif yang berkait dengan proses penuaan. Beberapa dari penyakit tidak menular tersebut antara lian, diabetes mellitus, hipertensi, penyakit jantung dan stroke. Penyakit-penyakit tersebut secara disebabkan oleh dua faktor yaitu faktor risiko yang tidak dapat diubah dan faktor risiko yang dapat diubah. Faktor risiko yang tidak dapat berubah misalnya jenis kelamin, umur, dan faktor genetic. Faktor risiko yang dapat diubah misalnya kebiasaan merokok, pekerjaan, aktivitas fisik, kebiasaan merokok, konsumsi alkohol, Indeks Masa Tubuh, lingkar pinggang (Boehme et al., 2017).

Penyakit degeneratif ini dapat mempengaruhi kualitas hidup penderitanya. Pencegahan terhadap penyakit degeneratif ini dapat dilakukan sebelum terdiagnosa maupun sesudah terdiagnosa. Pencegahan yang dapat dilakukan dengan meningkatkan kesadaran akan faktor resiko, menjauhi faktor resiko dan melakukan cek kesehatan secara teratur. Peningkatan kesadaran dapat dilakukan dengan edukasi baik secara langsung maupun menggunakan teknologi. Edukasi dapat meningkatkan motivasi pasien terkait dengan kepatuhan managemen diri (Hallberg et al., 2016). Pencegahan yang lain dapat dilakukan dengan olahraga, misalnya pada pasien dengan diabetes mellitus, hasil penelitian menunjukkan jika olahraga dapat memperbaiki kadar glukosa darah, penurunan risiko komplikasi kardiovaskuler, dan penurunan berat badan (Colberg et al., 2016).

Masjid selain merupakan tempat beribadah diharapkan dapat menjadi pusat untuk kesejahteraan dan peningkatan kualitas hidup masyarakat di sekitarnya. 
Dalam hal ini, masjid dapat menjadi pusat untuk gerakan sehat melalui program edukasi kesehatan dan deteksi dini resiko penyakit degeneratif untuk masyarakat. Masjid di wilayah kelurahan Ngestiharjo, merupakan bagian dari wilayah kerja Puskesmas Kasihan 2. Data yang ada menunjukkan penyakit degenerative khususnya hipertensi dan diabetes mellitus merupakan kunjungan tertinggi untuk penyakit tidak menular di Puskesmas Kasihan 2 dimana angka kejadian terus meningkat sepanjang tiga tahun dari tahun 2009-2011 (Puskesmas Kasihan 2, 2018). Hasil observasi di Masjid Al-Amin Sidorejo, jamaah terdiri dari warga RT sekitar, dengan kapasitas sekitar 60-100 orang jamaah. Hasil observasi dan wawancara, saat ini kegiatan yang ada di masjid tersebut lebih berupa kegiatan untuk pengajian baik pengajian bapak-bapak, pengajian ibu-ibu dan untuk Tempat Pembelajaran AlQuran. Sementara kegiatan terkait bidang kesehatan belum terintegrasi, dimana pernah dilakukan kegiatan senam untuk ibu-ibu namun hanya dilaksanakan satu kali saja. Selain itu juga belum pernah dilakukan pendidikan kesehatan terkait penyakit degenerative dan skrining kesehatan. Beberapa jamaah masjid

Berdasarkan hal tersebut, , jamaah masjid perlu mendapat program gerakan sehat untuk pencegahan penyakit degeneratif, karena penyakit degeneratif seringkali tidak terdeteksi sampai akhirnya menimbulkan efek samping atau disabilitas. Tujuan kegiatan program pengabdian kepada masyarakat ini adalah meningkatkan pengetahuan jamaah masijid dalam dan penatalaksanaan di rumah untuk penyakit degeneratif khususnya hipertensi dan diabetes mellitus. Selain itu, pengabdian juga bertujuan untuk melakukan skrining kesehatan dengan pengukuran tekanan darah dan kadar gula darah sewaktu serta pelaksanaan senam diabetes mellitus.

\section{METODE}

Mitra pada kegiatan pengabdian masyarakat ini adalah dua masjid di desa kelurahan Ngestiharjo, yang dapat menampung 100an jamaah. Solusi untuk mengatasi situasi di area sekitar Masjid desa Ngestiharjo terkait pencegahan dan penatalaksanaan penyakit degeneratif dialkukan dengan tiga langkah yaitu:

1. Pendidikan kesehatan. Pendidikan kesehatan dilakukan dua kali. Target kegiatan ini adalah 50 peserta. Pada pendidikan kesehatan pertama, kegiatan ini berupa pemberian informasi dalam bentuk pendidikan kesehatan masal oleh perawat selama kurang lebih 30 menit dan diikuti sesi tanya jawab selama 15 menit. Pemberian materi diberikan melalui media power point, dan setiap peserta diberikan dua buah leaflet yang berisi informasi umum tentang hipertensi dan penatalaksaan hipertensi di rumah. Pendidikan kesehatan kedua dilakukan dengan konseling individu terkait hipertensi dan diabetes mellitus. Target peserta untuk pendidikan kesehatan individu adalah peserta dengan tekanan darah diatas normal $(>130 / 90 \mathrm{mmHg})$ dan GDS (>120 gr/dl) dianjurkan untuk mengikuti pendidikan kesehatan individu. Pemberian informasi diberikan secara langsung dan peserta mendapatkan buku panduan penatalaksaan diabetes mellitus di rumah dan leaflet tentang hipertensi. Konseling individu dilakukan satu peserta dan satu pemateri.

2. Pemeriksaan tekanan darah dan gula darah sewaktu. Pemeriksaan tekanan darah dilakukan dengan tensimeter digital, sedangkan pemeriksaan gula darah sewaktu (GDS) dilakukan dengan alat glucotest. Target peserta ini adalah 50 orang. Pemeriksaan tekanan darah dan gula darah sewaktu dilakukan oleh perawat. Pengambilan gula darah untuk pemeriksaan GDS dilakukan dengan mengambil darah tepi danglucometer. Darah dimasukkan ke dalam strip test 
kemudian ditunggu 10 detik sehingga hasil terbaca oleh glucometer. Data tekanan darah dan GDS yang terbaca dicatat dalam form yang sudah disediakan.

3. Senam diabetes dilakukan dengan target 5-10 orang. Senam diabetes ditujukan untuk individu yang memiliki kadar GDS melebihi normal. Langkah ini dilakukan setelah konseling individu. Setiap individu dilatih oleh satu perawat. Sebelumnya perawat menjelaskan manfaat dari senam diabetes, kemudian menjelaskan dan memeragakan langkah senam diabetes dan diikuti oleh peserta.

Kelompok sasaran atau mitra untuk kegiatan ini adalah takmir masjid di wilayah desa Ngestiharjo. Mitra ini dilibatkan untuk pelaksanaan kegiatan pendidikan kesehatan, skrining kesehatan dan senam diabetes mellitus. Untuk kegiatan pengabdian masyarakat ini, mitra berpartisipasi aktif dengan menyediakan tempat dan fasilitas. Fasilitas yang disediakan berupa meja, kursi, dan pengeras suara. Selain itu mitra juga berperan dalam penyebaran informasi kegiatan sehingga jamaah yang hadir sesuai dengan yang ditargetkan.

Kegiatan dilakukan di dua masjid di wilayah desa Ngestiharjo dengan indikator keberhasilan jamaah masjid mengetahui mengenai hipertensi dan diabetes mellitus, dan mengetahui tekanan darah dan kadar GDSnya. Selain itu warga yang memiliki kadar GDS lebih dari normal dapat melakukan senam diabetes mellitus.

\section{HASIL DAN PEMBAHASAN}

Gerakan sehat berbasis masjid (rehatmas) untuk pencegahan dan penatalaksaan penyakit degeneratif khususnya hipertensi dan tekanan darah kepada jamaah masjid di desa Ngestiharjo yaitu di dukuh Sidorejo dan Sonopakis, Bantul berjalan dengan lancar. ProgramRehatmas in baik pada kegiatan pertama dan kedua dihadiri oleh jamaah masjid, pengurus pengajian ibu-ibu, dan takmir masjid. Jamaah masjid menunjukkan antusiasme yang baik sepanjang program. Jumlah peserta penyuluhan dan skrining kesehatan melebihi target yaitu pada pertemuan pertama 52 orang dan pada pertemuan kedua sebanyak 66 peserta. Jumlah peserta yang mengikuti senam diabetes mellitus sebanyak 10 orang. Antusiasme ini dimungkinkan karena adanya koordinasi tim pelaksana dengan pengurus pengajian dan takmir masjid, sehingga dapat menggerakan jamaah untuk hadir pada kegiatan tersebut.

Program Rehatmas yang sudah dilakukan menghasilkan dua produk, yaitu satu leaflet yang berisi mengenai penyakit hipertensi dan satu leaflet yang berisi penatalaksanaan hipertensi. Leaflet mengenai penyakit hipertensi berisi definisi, kategori hipertensi, penyebab hipertensi dan tanda dan gejala hipetensi. Leaflet kedua menjelaskan penatalaksanaan hipertensi baik secara farmakologis dan non-farmakologis. Pada leaflet tersebut penatalaksanaan nonfarmakologis menjelaskan mengenai teknik relaksasi, dan penggunaan herbal.

Pada pendidikan kesehatan pertama, peserta terlihat antusias mendengarkan materi yang diberikan. Saat sesi tanya jawab tidak ada peserta yang bertanya namun di akhir acara ada tiga jamaah yang bertanya secara pribadi ke tim pelaksana. Pada saat sesi tanya jawab, peserta Rehatmas dapat menjawab dengan tepat saat diajukan pertanyaan terkait tanda dan gejala dan penatalaksanaan. Pada acara pendidikan kesehatan kedua, semua peserta yang mengikuti antusias saat mendengarkan materi yang disampaikan. Peserta juga menanyakan pertanyaan terkait kondisi mereka seperti misalnya; apakah dosis insulin harus ditingkatkan karena kadar GDS yang cenderung terus naik. Satu peserta menangis terharu sesaat setelah mengikuti pendidikan kesehatan 
individual. Peserta tersebut mengatakan berterima kasih dengan informasi yang didapat dan juga mengetahui tekanan darah dan kadar GDSnya. Kelemahan kegiatan pendidikan kesehatan ini adalah tim tidak melakukan penyebaran soal baik pra dan paska kegiatan sehingga tidak dapat mengukur perubahan tingkat pengetahuan pemahaman sebelum dan sesudah pendidikan kesehatan.

Skrining kesehatan dilakukan dengan mengukur tekanan darah serta kadar gula darah. Peserta yang mengikuti skrining pada program Rehatmas I sebanyak 52 orang, namun ada 8 peserta yang tidak lengkap skriningnya, sehingga ada 44 yang dilakukan analisa. Pada skrining program Rehatmas II jumlah total peserta yang ikut sebanyak 66 orang namun ada 7 yang tidak lengkap dalam melakukan skrining. Ketidaklengkapan ini dikarenakan antrian yang cukup banyak sehingga beberapa memilih untuk tidak melakukan skrining lengkap. Pada gambar 1, baik pada screening I dan II mayoritas kadar gula darah sewaktu peserta masih dalam rentang normal $(70 \mathrm{mg} / \mathrm{dl}-120$ $\mathrm{mg} / \mathrm{dl}$ ). Saat kegiatan berlangsung, satu peserta mengatakan sudah didiagnosa diabetes mellitus sejak 15 tahun yang lalu, namun terkadang masih sering tidak mematuhi diet sehingga hasil pemeriksaannya GDS $>400 \mathrm{mg} / \mathrm{dl}$. Peserta tersebut mengatakan karena anaknya baru datang dari luar kota dan memasakkan nasi goreng yang sangat enak sehingga habis satu piring penuh.

Hasil skrining tekanan darah darah menunjukkan lebih dari 50\% peserta baik kadar systole maupun diastole lebih dari normal. Panduan dari AHA mengatakan individu dikatakan mengalami hipertensi jika tekanan systole $>130 \quad \mathrm{mmHg}$ dan diastole $>90 \mathrm{mmHg}$ (Whelton, 2017). Beberapa peserta kegiatan Rehatmas yang mengalami hipertensi mengatakan sudah tahu jika tekanan darahnya tinggi, namun masih tidak mematuhi obat. Ketidakpatuhan baik dalam manajemen gaya hidup dan pengobatan merupakan salah satu permasalahan yang cukup serius bagi penderita penyakit kronis misalnya hipertensi dan diabetes mellitus (Burnier, 2019). Lebih lanjut Burnier (2019) menyarankan untuk memperbaiki komunikasi antara petugas kesehatan dan pasien untuk meningkatkan kepatuhan pasien terhadap penatalaksanaan hipertensi.

Gambar 1. Gambaran tekanan systole,

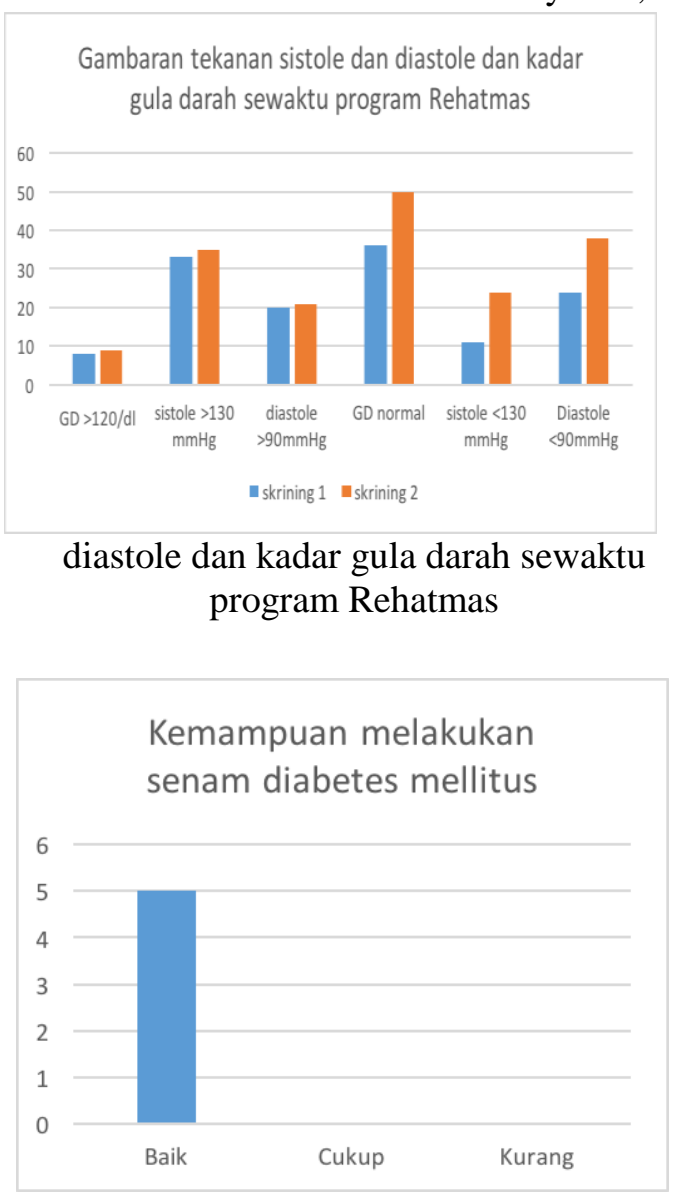

Gambar 2. Kemampuan peserta redemonstrasi senam diabetes mellitus

Senam diabetes mellitus diikuti oleh 5peserta khususnya peserta yang memiliki kadar GDS melebihi normal. Peserta antusias mengikuti demonstrasi senam yang dilakukan oleh tim pelaksana, dan dapat melakukan redemonstrasi dengan baik (gambar 2).Pelaksanaan senam pada pasien dengan diabetes 
mellitus efektif menurunkan kadar gula darah dibandingkan pada kelompok yang tidak melakukan senam (Utomo et al., 2012).Satu orang dengan penderita diabetes mellitus sekitar 15 tahun mengatakan pernah diajarkan mengenai senam kaki ini namun lupa. Peserta tersebut mengatakan terbantu dengan buku panduan penatalaksanaan diabetes di rumah yang diberikan saat sesi pendidikan kesehatan individu.

Penyakit degeneratif seperti hipertensi dan diabetes mellitus merupakan silent killer. Program Rehatmas yang telah dilakukan menunjukkan jika lebih dari 50\% peserta mengalami hipertensi dan banyak peserta yang tidak menyadari jika tekanan darahnya melebihi normal karena tidak memahami gejala dari hipertensi. Selain itu beberapa yang sudah mengetahui jika menderita hipertensi masih belum melakukan penatalaksanaan dengan tepat. Untuk itu diperlukan upaya peningkatan kepatuhan terhadap penatalaksanaan baik hipertensi maupun diabetes mellitus. Pemerintah dan institusi kesehatan dapat bekerja sama dengan mengintensifkan program yang sudah ada misalnya posyandu lansia.Upaya pengabdian kepada masyarakat yang dapat dilakukan adalah dengan pendidikan kesehatan yang dilakukan oleh peer dan pemilihan champion dari warga setempat untuk penatalaksanaan hipertensi dan diabetes mellitus.

\section{SIMPULAN}

Kegiatan pengabdian pada masyarakat ini memberi pengetahuan kepada jamaah masjid mengenai penyakit deneratif khususnya hipertensi dan diabetes mellitus dan penatalaksanaanya. Selain itu juga didapatkan baiknya kesadaran jamaah untuk memeriksaan diri saat skrining kesehatan. Pelaksanaan pendidikan kesehatan dan senam kaki diabetes mellitus memberikan dampak terhadap peningkatan pengetahuan dan kemampuan jamaah masjid di dukuh Sidorejo dan Sonopakis.

\section{UCAPAN TERIMAKASIH}

Kegiatan Pengabdian kepada Masyarakat ini dibiayai oleh Universitas Muhammadiyah Yogyakarta, sesuai dengan Surat Keputusan Kepala LP3M perjanjian Nomor: 2816/SK-Lp3M/I/2019 Tanggal 10 Januari 2019 Tentang Penerima Hibah Pengabdian Masyarakat Batch 1 Program Peningkatan Tri Dharma Perguruan Tinggi Tahun Akademik 2018/2019.

\section{DAFTAR PUSTAKA}

Al-Lawati, J. A. (2017). Diabetes Mellitus: A Local and Global Public Health Emergency! Oman Medical Journal, 32(3), 177-179.

Boehme, A. K., Esenwa, C., \& Elkind, M. S. V. (2017). Stroke risk factors, genetics and prevention. Circulation Research, 120, 472495.

Burnier, M. (2019). Improving blood pressure control in hypertensive population: challenges of low adherence and early discontinuation Hypertension. doi:https://doi.org/10.1161/HYPE RTENSIONAHA.119.12598

Colberg, S. R., Sigal, R. J., Yardley, J. E., Riddell, M. C., Dunstan, D. W., Dempsey, P. C., Tate, D. F. (2016). Physical Activity/Exercise and Diabetes: A Position Statement of the American Diabetes Association. Diabetes Care, 39(11), 20652079.

doi:https://doi.org/10.2337/dc16$\underline{1728}$

Hallberg, I., Ranerup, A., \& Kjellgren, K. (2016). Supporting the selfmanagement of hypertension: Patients' experiences of using a 
mobile phone-based system. Journal of Human Hypertension, 30(2), 141-146. doi: 10.1038/jhh.2015.37

Kementrian Kesehatan. (2018). Riskesdas 2018.

Mills, K. T., BUndy, J. D., Kelly, T. N., Reed, J. E., Kearney, P. M., Reynolds, K., . . . He, J. (2016). Global Disparities of Hypertension Prevalence and Control: A Systematic Analysis of Population-based Studies from 90 Countries. Circulation, 134(6), 441-450. doi:doi: 10.1161/CIRCULATIONAHA. 11 5.018912

Puskesmas Kasihan 2. (2018). Kunjungan Puskesmas Kasihan II Tahun 2008, 2009, 2010. Retrieved from https://puskesmas.bantulkab.go.id /kasihan2/data-kesehatan/

Utomo, U. M., Azam, M., \& Anggarini, D. N. (2012). Pengaruh senam terhadap kadar gula darah peserta diabetes. Unnes Journal of Public Health, 1(11), 36-40.

Whelton, P. K. (2017). New ACC/AHA high blood pressure guidelines lowe definition of hypertension American College of Cardiology. 